Original Article

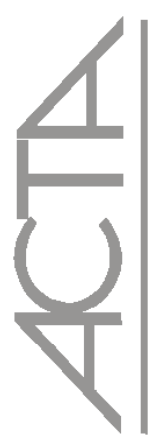

\title{
Nursing intervention in insulin administration: telephone follow-up*
}

\author{
Intervenção de enfermagem na aplicação de insulina: acompanbamento por telefone \\ Intervención de enfermería en la aplicación de insulina: acompañamiento por teléfono
}

\author{
Tânia Alves Canata Becker', Carla Regina de Souza Teixeira ${ }^{2}$, Maria Lucia Zanetti ${ }^{3}$
}

\begin{abstract}
Objective: To analyze the competency of people with diabetes mellitus to perform the insulin administration process, before and after telephone monitoring. Methods: A quantitative, observational, longitudinal, comparative study. Participants were 26 people enrolled in the at-home capillary glycemia self-monitoring program. Data collection occurred in three phases, in January and February of 2010 , for a period of 30 days for each person, by means of interview guided by a data collection instrument and an intervention manual. Results: Of the 38 (100\%) questions referring to the insulin administration process, telephone monitoring was demonstrated to be efficient in 30 (78.9\%), but in 19 (50\%) the intervention was statistically significant $(\mathrm{p}<0.05)$, in $11(28.9 \%)$ there were no errors in responses to the final competency evaluation, and seven $(18.4 \%)$ were not amenable to intervention. Conclusion: Telephone mornitoring was effective, as a nursing intervention strategy for the insulin administration process in the home.
\end{abstract}

Keywords: Insulin; Diabetes mellitus; Nursing Care; Telephone

\section{RESUMO}

Objetivo: Analisar a competência da pessoa com Diabetes mellitus para realizar o processo de aplicação de insulina, antes e após o acompanhamento por telefone. Métodos: Estudo de abordagem quantitativa, observacional, longitudinal, comparativo. Participaram 26 pessoas cadastradas no programa de automonitorização da glicemia capilar no domićlio. A coleta de dados ocorreu em três fases, entre janeiro e fevereiro de 2010, no período de 30 dias para cada pessoa, por meio de entrevista, norteada pelo instrumento de coleta de dados e o manual de intervenção. Resultados: Das $38(100 \%)$ questões referentes ao processo de aplicação de insulina, o acompanhamento por telefone demonstrou-se eficiente em 30 $(78,9 \%)$, pois em $19(50 \%)$ a intervenção foi estatisticamente significante ( $\mathrm{p}<0,05)$, em 11(28,9\%) não houve erros nas respostas na avaliação da competência final e sete $(18,4 \%)$ não eram passíveis de intervenção. Conclusão: O acompanhamento por telefone foi efetivo, como estratégia de intervenção de enfermagem no processo de aplicação de insulina no domicílio.

Descritores: Insulina/uso terapêutico; Diabetes mellitus/enfermagem; Cuidados de enfermagem; Telefone

\section{RESUMEN}

Objetivo: Analizar la competencia de la persona con Diabetes mellitus para realizar el proceso de aplicación de insulina, antes y después de acompañamiento por teléfono. Métodos: Se trata de un estudio de abordaje cuantitativo, observacional, longitudinal, comparativo. Participaram 26 personas registradas en el programa de automonitorización de la glicemia capilar en el domicilio. La recolección de los datos se llevó a cabo em tres fases, entre enero y febrero del 2010, en el período de 30 días para cada persona, por medio de entrevista, orientada por el instrumento de recolección de datos y el manual de intervención. Resultados: De las 38 (100\%) preguntas referentes al proceso de aplicación de insulina, el acompañamiento por teléfono demostró que es eficiente en 30 (78,9\%), pues en 19(50\%) la intervención fue estadísticamente significativa $(\mathrm{p}<0,05)$, en $11(28,9 \%)$ no hubo errores en las respuestas en la evaluación de la competencia final y siete $(18,4 \%)$ no eran pasibles de intervención. Conclusión: El acompañamiento por teléfono fue efectivo, como estrategia de intervención de enfermería en el proceso de aplicación de insulina en el domicilio.

Descriptores: Insulina/uso terapéutico; Diabetes mellitus/enfermería; Atención de enfermería; Teléfono

\footnotetext{
* Study conducted at University of São Paulo - USP - Ribeirão Preto (SP), Brazil. Awarded research by the Minister of Health with honors in the Master's Degree Category of the Incentive Award for Science and Technology to UHS - 2011 website: http:// bvsms.saude.gov.br/bvs/publicacoes/premio_ciencia_tecnologia_2011.pdf ${ }^{1}$ Master of Science in School of Nursing, Ribeirão Preto, University of São Paulo-USP - Ribeirão Preto (SP), Brazil.

${ }^{2}$ Advisor. Associated Professor of Specialized and General Nursing Department at School of Nursing, Ribeirão Preto, University of São Paulo - USP - Ribeirão Preto (SP), Brazil.

${ }_{3}^{3}$ Associated Professor of Specialized and General Nursing Department at School of Nursing, Ribeirão Preto, University of São Paulo - USP - Ribeirão Preto (SP), Brazil.
} 


\section{INTRODUCTION}

Diabetes mellitus (DM) is a chronic condition that requires continuous management and today is considered as a worldwide epidemic, resulting in challenge to health systems worldwide ${ }^{(1)}$. In 1985, 30 million adults with DM worldwide were estimated, that number grew to 135 million in 1995, reaching 173 million in 2002, being projected to reach 300 million by $2030^{(2)}$.

In 2000, Brazil ranked eighth among the ten countries with the highest number of DM cases, about 4.6 million, projected, by 2030 , to achieve sixth place, with 8.9 million diagnosed people ${ }^{(2)}$. In a more recent study, conducted in the city of Ribeirão Preto in 2005/2007, with the urban population from 30 to 79 years old, it was verified an increased prevalence of DM and impaired glucose tolerance compared to national and regional studies, $15.02 \%$ and $5.53 \%$ respectively ${ }^{(3)}$. In this regard, DM constitutes a threat to all countries from the economic and health perspective. Thus, investing in prevention, early detection and treatment is critical to ensure a better quality of life and decrease hospitalization expenditures and high-tech medical procedures ${ }^{(4)}$.

In 2007, a Brazilian study identified the direct and indirect costs of ambulatory treatment for people with T2DM in the Unified Health System (UHS). Data were collected in health facilities of different levels of care (primary, secondary and tertiary) of eight Brazilian cities in 2007 , with the participation of 1,000 people. The results showed an annual cost of ambulatory treatment for people with T2DM of $\mathrm{R} \$ 2,951,496.00$ for 1,000 patients ( $\mathrm{R} \$ 2,951.00$ / per person), and $\mathrm{R} \$ 1,870,365.00$ of direct costs $(63,3 \%)$ and $\mathrm{R} \$ 1,082,496.00$ of indirect costs $(36.7 \%)^{(5)}$.

According to the Brazilian Diabetes Society $(2011)^{(6)}$, treatment of DM includes the following strategies: education, modification of lifestyle that includes smoking cessation, increase in physical activity, reorganization of nutritional habits and if necessary, the use of drugs. In this regard, thanks to the prognostic characteristics of $\mathrm{DM}$, treatment over the years requires the use of drugs, oral antidiabetic agents and insulin, since the pancreatic beta cells tend to progress to a state of partial or total failure along the years ${ }^{(6)}$.

The goal of insulin therapy is to bring subjects to the maximum of their prior condition to the onset of DM, ie the physiological profile of normal pancreatic insulin secretion. Thus, multiple daily doses of insulin into the subcutaneous tissue are needed to establish glycemic control, which has been demonstrated as essential in the prevention of chronic complications of this disease ${ }^{(7)}$. Nonetheless, for the insulin therapy treatment to reach glycemic control, learning various aspects of the use of exogenous insulin is necessary, because its action is directly related to factors such as: type of insulin, dose, concentration, technique for mixing of insulin's, site of administration and administration technique ${ }^{(6)}$.

In Brazil, a pioneering study that investigated the administration of insulin in people with DM at home showed a growing concern with errors related to its application ${ }^{(8)}$. Another concern relates to the behavior of people with DM regarding the use and/or reuse of disposable syringes, in which $94.6 \%$ reused disposable syringe and needle, after use $\mathrm{e}^{(9)}$. Another study found that $64.7 \%$ of people had complications on site of administration, and these related mainly to inadequate insulin administration technique ${ }^{(10)}$. A bibliographic research of studies about the reuse of disposable syringes, complications in the sites of administration and microbiological changes in insulin syringes reused, found the highest number of publications in the United States of America (46.3\%), England (19.5\%) and Brazil $(17 \%)^{(11)}$. The study triggered a broad reflection among health professionals who provide care to people with DM using insulin, and highlights several gaps in relation to the theme, suggesting the need for future studies in our country.

In this context, the quality of care for people with $\mathrm{DM}$ is still poor in Brazil due to unawareness of basic procedures for the improvement of skills for insulin administration, such as: delimitation of the site of administration, rotation of sites of administration, temperature of insulin storage, among others ${ }^{(12,13)}$. Thus, after the identification of the variables involved in the insulin administration, it is necessary to seek measures to help the continuity of care for the development of confidence and technical skills through educational interventions ${ }^{(14)}$.

Considering the progress of DM and economic challenges because of the scarcity of financial and human resources, new strategies of easy implementation by health systems are needed to be developed, with the potential to assist a large number of people and with low cost ${ }^{(15)}$. From this perspective, the telephone appears as a potential tool for the comprehensive care that translates into an expansion of health action, representing an evolution on the traditional nursing $\operatorname{care}^{(16,17)}$.

Within this context, this study aimed to analyze the competence of people with DM to perform the insulin administration procedure at home, before and after the follow-up by telephone.

\section{METHODS}

This is a quantitative, observational, longitudinal, comparative type of before and after study. The population consisted of 26 people with DM enrolled in the program of self-monitoring of blood glucose in 
a university health center in a city of São Paulo State, meeting the following criteria: be 18-65 years of age; consent to participate in the study; participate in $75 \%$ of the phone calls and self-declare that performs the insulin administration procedures technique without the help of a caregiver. Data collection was conducted over a period of 30 days for each person, Monday through Friday, respecting the contract of one call a week, totaling four calls between January and February 2010.

The dynamics of data collection was conducted by three stages: Stage 1: Called assessment of initial competence (IC). The researcher conducted the first telephone contact, in which the invitation to participate in the study and reading of the consent form were made, the acceptance to participate in the study was recorded. After that, the researcher applied the instrument to collect data, previously elaborated with 52 questions, in two parts; the first part consisted of 14 questions on sociodemographic, clinical and anthropometric variables; the second part consisted of 38 questions about the variables related to telephone monitoring of insulin administration procedures at home, from these, seven questions were not amenable to educational intervention. Stage 2: Two calls with an educational approach were conducted. For this, the researcher developed a handbook of intervention composed by codes ([1] - do not apply intervention (correct answer); [2] - apply intervention (wrong answer) and [0] - question did not allow intervention) indicating in each answer the alternative of the instrument for data collection when intervention would be performed, considering to facilitate the planning for the second and third call with educational approach. At this stage, there was also the dimensioning of content during calls, whose aim was to avoid fatigue and loss of information discussed with the person during follow-up by phone. By dimensioning the questions that would be addressed, the researcher wrote a plan for caring similar to a report, based on the handbook of nursing intervention developed for this study. Stage 3: Application of data collection instrument for the assessment of final competence (FC). At the end of the instrument for data collection application, the participant received information about the end of the study, also a moment to comment.

To organize data, we created a database on Microsoft Excel, XP version (Microsoft CO, USA), with double entry of data that were then imported to the Statistical Analysis System (SAS ${ }^{\circledR}$ 9.0, using the PROC GLM. The analysis of data related to sociodemographic, clinical and anthropometric variables occurred by using descriptive statistics. For the analysis of data related to the comparison of the duration of calls, we used the methodology of analysis of variance (ANOVA) ${ }^{(18)}$. For data relating to the comparison of IC and FC of people with DM in relation to the insulin administration procedures at home, we used the McNemar test ${ }^{(19)}$, which is applied to cases in which each element is taken as its own control, so we had two situations: before and after the follow-up by telephone.

Regarding ethical issues, the Ethics Research Committee of the School Health Center Prof. Dr. Joel Domingos Machado, under protocol 302/2009, approved this study.

\section{RESULTS}

From $26(100 \%)$ participants interviewed, 21 $(80.77 \%)$ were female, five $(19.23 \%)$ were male. In addition, it was found that most were married 19 $(69.23 \%)$, with uncompleted primary school six $(23.08 \%)$ and household nine (34.62\%). Regarding clinical variables, the lowest time of diagnosis of DM declared was five years and the highest 30 years, with a median of 14 years and 6 months. Regarding the time of insulin use, the lowest was one year and the highest 30 years, with a median of seven years. With regard to the anthropometric variables, the lowest declared weight of $49 \mathrm{~kg}$ and the highest of $115 \mathrm{~kg}$ with a median of $79 \mathrm{~kg}$. It was, also found that, the lowest declared height was $145 \mathrm{~cm}$ and the highest $184 \mathrm{~cm}$, with a median of $157 \mathrm{~cm}$. Accordingly, after calculations performed by the researcher, the lowest body mass index (BMI) was $19 \mathrm{~kg} / \mathrm{m}^{2}$ and the highest $54 \mathrm{~kg} / \mathrm{m}^{2}$, with a median of $30.5 \mathrm{~kg} / \mathrm{m}^{2}$. There was a prevalence of 17 (65.38\%) people aged between 50-59 years, with a median of 56 years. Regarding the analysis of the competence of the person with DM, $38(100 \%)$ questions were related to the insulin administration procedure, in seven $(18.4 \%)$ they were not able to make intervention and in $31(81.6 \%)$ intervention was possible. Of these, the telephone follow-up proved to be effective in $30(78.9 \%)$, and in $19(50 \%)$ questions the intervention was statistically significant $(p<0.05)$, as shown in the data in Table 1.

As for $11(28.9 \%)$ remaining questions which allowed intervention, there were no errors in the answers of people with DM in the FC evaluation, as indicated in the data in Table 2. It is worth mentioning that thanks to the $100 \%$ accuracy in FC, it was not possible to calculate the statistical significance by the McNemar test. Among the steps which allowed intervention, only the one related to the observation of the insulin characteristics did not have statistical significant difference after the intervention, with $\mathrm{p}=0.1573$. 
Table 1. Evaluation of 19 questions with statistical significant for initial and final competence of studied population. Ribeirão Preto, 2010

\begin{tabular}{|c|c|c|c|c|}
\hline Knowledge & Categories & $\begin{array}{c}\text { IC* } \\
\text { n(\%) }\end{array}$ & $\begin{array}{l}\text { FC* } \\
\text { n(\%) }\end{array}$ & p-value \\
\hline \multirow[t]{3}{*}{ Insulin type } & $\mathrm{NPH}$ & $12(46.15)$ & $15(57.69)$ & \multirow{3}{*}{0.0143} \\
\hline & Regular+NPH & $08(30.77)$ & $08(30.77)$ & \\
\hline & Does not know & $06(23.08)$ & $03(11.54)$ & \\
\hline \multirow[t]{2}{*}{ Size of insulin syringe } & $100 \mathrm{IU}$ & $17(65.39)$ & $25(96.15)$ & \multirow{2}{*}{0.0047} \\
\hline & Does not know & $09(34.62)$ & $01(3.85)$ & \\
\hline \multirow[t]{2}{*}{ Syringe graduation } & $2 \mathrm{UI}$ & $10(38.46)$ & $21(80.77)$ & \multirow{2}{*}{0.0009} \\
\hline & Does not know & $16(61.54)$ & $05(19.23)$ & \\
\hline \multirow[t]{2}{*}{ Needle size } & $12,7 \times 0,33 \mathrm{~mm}$ & $01(3.85)$ & $12(46.16)$ & \multirow{2}{*}{0.0009} \\
\hline & Does not know & $25(96.15)$ & $14(53.85)$ & \\
\hline \multirow[t]{2}{*}{ Insulin storage } & Refrigerator (door) & $25(96.15)$ & $21(80.77)$ & \multirow{2}{*}{$<0.001$} \\
\hline & refrigerator (drawer) & $01(3.85)$ & $05(19.23)$ & \\
\hline \multirow[t]{2}{*}{ Insulin removal of cooler } & Yes & 05(19.23) & $17(65.38)$ & \multirow{2}{*}{0.0005} \\
\hline & No & $21(80.77)$ & $09(34.62)$ & \\
\hline \multirow[t]{2}{*}{ Rubber disinfection of the insulin flask } & Yes & $13(50.00)$ & $24(92.31)$ & \multirow{2}{*}{0.0009} \\
\hline & No & $13(50.00)$ & $02(7.69)$ & \\
\hline \multirow[t]{2}{*}{ Air introduction on insulin flask } & Yes & $12(46.15)$ & $20(76.92)$ & \multirow{2}{*}{0.0047} \\
\hline & No & $14(53.85)$ & $06(23.08)$ & \\
\hline \multirow[t]{2}{*}{ Positioning of insulin flask } & Yes & $19(73.08)$ & $24(92.31)$ & \multirow{2}{*}{0.0253} \\
\hline & No & $07(26.92)$ & $02(7.69)$ & \\
\hline \multirow[t]{2}{*}{ Air bubles removal } & Yes & $15(57.69)$ & $23(88.46)$ & \multirow{2}{*}{0.0047} \\
\hline & No & $11(42.31)$ & $03(11.54)$ & \\
\hline \multirow[t]{2}{*}{ Dose adjustment } & Yes & $15(57.69)$ & $23(88.46)$ & \multirow{2}{*}{0.0047} \\
\hline & No & $11(42.31)$ & $03(11.54)$ & \\
\hline \multirow[t]{2}{*}{ Needle recapping } & Yes & $18(69.23)$ & $24(92.31)$ & \multirow{2}{*}{0.0143} \\
\hline & No & $08(30.77)$ & $02(7.69)$ & \\
\hline \multirow[t]{2}{*}{ Skin antisepsis } & Yes & $14(53.85)$ & $20(76.92)$ & \multirow{2}{*}{0.0143} \\
\hline & No & $12(46.15)$ & $06(23.08)$ & \\
\hline \multirow[t]{2}{*}{ Needle degree of insertion } & Yes & $18(69.23)$ & $25(96.15)$ & 0002 \\
\hline & No & $08(30.77)$ & $01(3.85)$ & \\
\hline Syringe aspiration & Yes & $08(30.77)$ & $21(80.77)$ & مOPOP \\
\hline & No & $18(69.23)$ & 05(19.23) & .0003 \\
\hline Five seconds waiting for needle removal & Yes & $07(26.92)$ & $21(80.77)$ & בחתח0 \\
\hline & No & $19(73.08)$ & $05(19.23)$ & 0.0002 \\
\hline Massage on the site of administration & Yes & $15(57.69)$ & 04(15.38) & POPQ? \\
\hline & No & $11(42.31)$ & $22(84.62)$ & 0.0002 \\
\hline Insulin flask expiration date & Yes & $03(11.54)$ & $24(92.31)$ & $<0001$ \\
\hline & No & $23(88.46)$ & $02(7.69)$ & -0.001 \\
\hline Disposal of needlestick material & Yes & $19(73.08)$ & $24(92.31)$ & 00253 \\
\hline & No & $07(26.92)$ & $02(7.69)$ & \\
\hline
\end{tabular}

n=26. CI: competência inicial. CF: competência final 
Table 2. Evaluation of 11 questions which allowed intervention on initial and final competence on studied population. Ribeirão Preto, 2010

\begin{tabular}{|c|c|c|c|}
\hline Knowledge & Categories & $\begin{array}{l}\mathrm{IC} * \\
\mathrm{n}(\%)\end{array}$ & $\begin{array}{l}\mathrm{FC} * \\
\mathrm{n}(\%)\end{array}$ \\
\hline Aspiration sequence & $\begin{array}{l}\text { Regular } \\
\mathrm{NPH}\end{array}$ & $\begin{array}{l}04(57.15) \\
03(42.85)\end{array}$ & $\begin{array}{c}07(100) \\
0(0)\end{array}$ \\
\hline Instrumental type & Disposable syringe with fixed needle & $26(100)$ & $26(100)$ \\
\hline Site of insulin administration & $\begin{array}{l}\text { Abdomen } \\
\text { Posterior portion of arm } \\
\text { Lateral portion of thigh } \\
\text { Posterior portion gluteal site }\end{array}$ & $\begin{array}{l}21(80.77) \\
12(46.15) \\
13(50.00) \\
07(26.92)\end{array}$ & $\begin{array}{l}21(80.77) \\
16(61.53) \\
15(57.69) \\
08(30.77)\end{array}$ \\
\hline Rotating the site selections & $\begin{array}{l}\text { Yes } \\
\text { No }\end{array}$ & $\begin{array}{l}19(73.08) \\
07(26.92)\end{array}$ & $\begin{array}{c}26(100) \\
0(0)\end{array}$ \\
\hline Site of application observation & $\begin{array}{l}\text { Yes } \\
\text { No }\end{array}$ & $\begin{array}{l}21(80.77) \\
05(19.23)\end{array}$ & $\begin{array}{c}26(100) \\
0(0)\end{array}$ \\
\hline Recipient packing with ice & $\begin{array}{l}\text { Separated from ice } \\
\text { Direct contact with ice }\end{array}$ & $\begin{array}{l}12(57.14) \\
09(34.61)\end{array}$ & $\begin{array}{c}26(100) \\
0(0)\end{array}$ \\
\hline Recipient packing without ice & & $05(100)$ & 05(100) \\
\hline Wash hands & $\begin{array}{l}\text { Yes } \\
\text { No }\end{array}$ & $\begin{array}{l}25(96.15) \\
01(3.85)\end{array}$ & $\begin{array}{c}26(100) \\
0(0)\end{array}$ \\
\hline Shake insulin NPH & Yes & $26(100)$ & $26(100)$ \\
\hline Do the skinfold before administration & $\begin{array}{l}\text { Yes } \\
\text { No }\end{array}$ & $\begin{array}{l}21(80.77) \\
05(19.23)\end{array}$ & $\begin{array}{c}26(100) \\
0(0)\end{array}$ \\
\hline Previous preparation for needlestick material disposal & $\begin{array}{l}\text { Recapped neddle } \\
\text { Bends the needle } \\
\text { Break the needle }\end{array}$ & $\begin{array}{c}21(80.77) \\
03(11.54) \\
02(7.69)\end{array}$ & $\begin{array}{c}26(100) \\
0(0) \\
0(0)\end{array}$ \\
\hline
\end{tabular}

$\mathrm{n}=26$. IC: initial competence. FC: final competence

With regard to the seven questions which did not allow participant's intervention, we found that only seven $(26.92 \%)$ participants were mixing regular and $\mathrm{NPH}$ insulin in the same syringe, $14(53.85 \%)$ used insulin administration twice a day, $14(53.85 \%)$ reported having received some kind of guidance on the insulin administration and from these, eight (30.77\%) nursing professional were the responsible person. Regarding the transport of insulin flask, 21 (80.77\%) participants used a recipient with ice and none reported any difficulty in getting the supplies from the public health center.

For the conduction of this study, 308 telephone calls were made, totaling 25 hours and 20 minutes of duration. The mean duration of calls were 10 minutes in the IC and 8 minutes in the FC. For the educational approach, the mean duration was 10 and 12 minutes, in the first and second call, respectively.

\section{DISCUSSION}

In the present study, with respect to the gender of the participants, we found a similar predominance of females in a literature review study that examined eight publications between the years 1990-2008, from these, seven presented a higher female frequency, ranging between $53 \%-70 \%{ }^{(15)}$.

It is recognized that education is a factor that must be considered in the proposition of care through telephone contact, in the same way as educational activities in group. In this direction, the low educational level of most participants, constituted as a risk factor, as previous studies ${ }^{(3-20)}$.

When considering the predominance time of diagnosis between 11-20 years, it is possible that people over the years have received some positive information related to pathogenesis. However, monitoring by telephone can be a facilitator in this process because of its flexibility, due to the fast access to information, often and mostly convenient to elderly people with limited mobility or who live in remote locations, far from experts ${ }^{(21)}$.

The importance of marital status reveals itself in the sense that organized and structured families provide a more appropriate environment to support the care of 
people with DM, influencing their behavior given their partner collaboration to achieve a good metabolic control ${ }^{(22)}$. The same way as a person who is economically active can achieve greater personal satisfaction, social interaction, favoring physical and mental health, which can help to reduce stress and depression ${ }^{(23)}$.

Obesity or having excess of weight are relevant factors for planning educational interventions in DM. It is estimated this condition is present in $80 \%$ of people with $\mathrm{T} 2 \mathrm{DM}^{(6)}$, and this condition increases the risk of death in four times ${ }^{(24)}$. Its relevance demonstrates that efforts should be increased to its prevention through the development of new strategies for health education, as seen in this study the BMI median among participants was $30.5 \mathrm{~kg} / \mathrm{m}^{2}$.

Among the stages of the insulin administration procedures, we highlight the knowledge of the syringe and needle as indispensable tools for the procedure, with predominance of plastic disposable syringe graduated in $100 \mathrm{IU}$, because of its lower cost, ease of acquisition and material handling ${ }^{(9)}$. However, in large part the evaluation of IC, participants did not known the size of the needle for administering insulin, which is an indispensable information due to the risk associated with injuries, such as: intramuscular administration with larger needles, leading to faster absorption and hypoglycemia ${ }^{(25)}$.

It is worth mentioning the knowledge about differences in grading scales between insulin syringes 30IU, $50 \mathrm{IU}$ and $100 \mathrm{IU}$, whereas in a recent study $24.9 \%$ of the participants with DM cited difficulties in visualizing the dosage of insulin in the syringe, $10.6 \%$ reported motor difficulties during aspiration technique and $36.1 \%$ aspirated different dosage from the prescribed ${ }^{(13)}$.

Thus, through monitoring by telephone, we sought to contemplate another point discussed by another study ${ }^{(13)}$, such as not understanding that every graduation bar is equivalent to two units of insulin (syringes with volumetric capacity of $100 \mathrm{IU}$ ). Likewise, there was a predominance of insulin storage in the refrigerator at IC $(96.15 \%)$, in agreement with the results of this study ${ }^{(13)}$ in which $81.7 \%$ of people reported using the refrigerator door.

In the study, we found a median of seven years of insulin use, suggesting that they had experience in relation to the preparation technique and administration. However, $100 \%$ of participants failed at some point. In this direction, monitoring by telephone can be a facilitator in health education for its flexibility, because the information access is fast, frequent and often convenient for people with limited mobility or who lived in remote locations far from experts ${ }^{(21)}$.

For the conduction of the study, multiple calls were necessary. However, the small number of participants
( $n=26)$ may be because of the fact that people do not knew the researcher. In this direction, gaining the trust of the participant in the first telephone contact demanded the researcher exercising skills in the communication process. Therefore, it is recommended that the initial presentation of the telephone research is conducted face to face.

During educational approach calls, the encouragement for the insulin administration considering rotating plans was possible to achieve, as recommended by the Brazilian Diabetes Society $(2011)^{(6)}$, because no participant in the IC reported administered insulin in inadequate site; however, there was an increase in administration referred to the posterior portion of the arm in the FC evaluation.

Nursing practice associated with telephone use, as a resource for continuing education can produce significant changes in the ability to adjust to the new health condition, highlighting the importance of technical and clinical knowledge of nursing interventions. Nevertheless, the use and development of communication technologies in health care require more prepared professionals to promote convergence between human and technological development, in an attempt to achieve a healthy and supportive social competence.

From the acquisition of insulin in the health service to the administration at home, there are variables that can interfere in the therapy with insulin expected result, as was considered in this study. Conversely, insulin administration is a procedure, and learning this behavior through speaking by telephone demanded skills by the researcher involved. It is considered, therefore, that the best way is to observe at home. However, such data collection would require more time and greater cost to realization. Thus, the present study showed an intermediate way of support, ie, at times that the transport of people/professional or service in a health care facility is not possible.

In this perspective, this intervention model is not intended to replace the traditional group or individual care, since their effectiveness is proven by several national and international studies, but rather complement the service, because the telephone is a low-cost resource, accessible for much of the population and can be used for monitoring various health conditions.

In 2010, data were published about the new recommendations for the technique of insulin administration $^{(26)}$, a result of the joint committee of physicians, nurses, psychologists and educators from 27 countries, who gathered all publications in the area since 1980. The findings of this study were impacting to healthcare professionals and people with DM, since the recommendations, such as selection of needle size by BMI, skinfold prior to the needle administration, site selection 
for administration, among others, have changed and were discussed in the chapter about administration of insulin in the Guidelines of the Brazilian Society of Diabetes $(2011)^{(6)}$.

As a result, we emphasize that the person with DM with the professional involved in the education process must continuously seek excellence in self-care, the telephone follow-up being a viable strategy for health promotion.

\section{CONCLUSION}

In this study, the results showed the necessity of developing a reorientation process of care for people with DM in health services, because it is not enough to

\section{REFERENCES}

1. International Diabetes Federation. IDF International Standards for Diabetes Education. 3rd ed. Brussels: International Diabetes Federation; 2009.

2. Wild S, Roglic G, Green A, Sicree R, King H. Global prevalence of diabetes: estimates for the year 2000 and projections for 2030. Diabetes Care. 2004; 27(5): 1047-53.

3. Moraes SA, Freitas IC, Gimeno SG, Mondini L. [Diabetes mellitus prevalence and associated factors in adults in Ribeirão Preto, São Paulo, Brazil, 2006: OBEDIARP Project]. Cad Saúde Pública. 2010; 26(5): 929-41.

4. Organização Mundial da Saúde - OMS. Cuidados inovadores para condições crônicas: componentes estruturais de ação: relatório mundial. Brasília (DF): Organização Mundial da Saúde; 2003. 105 p.

5. Bahia L, Araujo DV, Schaan BD, Dib SA, Negratto CA, Gomes MB, et al. Custos do tratamento ambulatorial do diabetes mellitus tipo 2 no sistema único de saúde (SUS) [abstract]. Arq Bras Endocrinol Metabol. 2009; 53:1008. [Apresentado no $17^{\circ}$ Congresso da Sociedade Brasileira de Diabetes; 2009; Fortaleza-CE].

6. Sociedade Brasileira de Diabetes -SBD. Diretrizes da Sociedade Brasileira de Diabetes: Tratamento e acompanhamento do diabetes mellitus. Itapevi: Sociedade Brasileira de Diabetes; 2011.

7. The effect of intensive treatment of diabetes on the development and progression of the long-term complications in insulin-dependent diabetes mellitus. The Diabetes Control and Complications Trial Research Group. N Engl J Med.1993; 329(14): 977-86.

8. Mendes IA. Observação da administração de insulina em pacientes diabéticos no domicílio [dissertação]. Rio de Janeiro: Universidade Federal do Rio de Janeiro, Escola de Enfermagem Ana Néri; 1975.

9. Souza CR, Zanetti ML. [The use of disposable syringes in the administration of insulin at home]. Rev Latinoam Enferm. 2001; 9(1): 39-45. Portuguese.

10. Camata DG. [Local complications in the skin related to the administration of insulin]. Rev Latinoam Enferm. 2003; 11(1): 119-22. Portuguese.

11. Castro AR, Graziano KU, Grossi SA. Alterações nos locais de aplicação de insulina e nas seringas reutilizadas pelos pacientes diabéticos. Rev Gaúcha Enferm. 2006; 27(1): 27-34.

12. Cândido CB, Zanetti ML, Prado KR. Complicações locais na pele relacionadas à aplicação de insulina. Rev Enferm UERJ. 2002; 10(1): 38-40. offer supplies, but it is necessary to evaluate how it has been used, considering the complexity of the insulin administration procedure.

In this regard, future studies direction should point to clarify the most effective use of this intervention strategy for the monitoring of other chronic conditions. Therefore, it is suggested that studies about the comparison of educational groups approach, by telephone or hybrid, are compared to the evaluation of the impact of each type of monitoring by evaluating clinical parameters such as: glycated hemoglobin levels, waist circumference, blood pressure, among others, considering the international research on the use of new technologies in health.

13. Stacciarini TS, Haas VJ, Pace AE. [Factors associated with insulin self-administration by diabetes mellitus patients in the Family Health Strategy]. Cad Saúde Pública. 2008; 24(6): 1314-22. Portuguese.

14. Torres HC, Souza ER, Lima MH, Bodstein RC. Educational intervention for self-care of individuals with diabetes mellitus. Acta Paul Enferm. 2011; 24(4): 514-9.

15. Graziano JA, Gross CR. The effects of isolated telephone interventions on glycemic control in type 2 diabetes: a literature review. ANS Adv Nurs Sci. 2009; 32(3): E28-41.

16. Peck $A$. Changing the face of standard nursing practice through telehealth and telenursing. Nurs Adm Q. 2005; 29(4):339-43.

17. Snooks HA, Williams AM, Griffiths LJ, Peconi J, Rance J, Snelgrove S, et al. Real nursing? The development of telenursing. J Adv Nur. 2008; 61(6): 631-40.

18. Montgomery DC. Design and analysis of experiments. 5th ed. New York: John Wiley \& Sons; 2000.

19. Campos H. Estatística experimental não-paramétrica. $4^{\mathrm{a}}$ ed. Piracicaba: Departamento de Matemática e Estatística da ESALQ-USP; 1983.

20. Torquato MT, Montenegro Júnior RM, Viana LA, Souza RA, Lanna $\mathrm{CM}$, Lucas JC, et al. Prevalence of diabetes mellitus and impaired glucose tolerance in urban population aged 30-69 years in Ribeirão Preto (São Paulo), Brazil. São Paulo Med J. 2003; 121(6):224-30.

21. Car J, Sheikh A. Telephone consultations. BMJ. 2003; 326(7396): 966-9.

22. Zanetti ML, Biaggi MV, Santos MA, Péres DS, Teixeira CR. [The care for the diabetic patient and family repercussion]. Rev Bras Enferm. 2008; 61(2): 186-92. Portuguese.

23. Kinder LS, Kamarck TW, Baum A, Orchard TJ. Depressive symptomatology and coronary heart disease in Type 1 diabetes mellitus: a study of possible mechanisms. Health Psychol. 2002; 21(6): 542-52.

24. Francischi RP, Pereira LO, Freitas CS, Klopfer M, Santos RC, Vieira P, et al. [Obesity: updated information about its etiology, morbidity and treatment]. Rev Nutr. 2000; 13(1): 17-28. Portuguese

25. Tubiana-Rufi N, Belarbi N, Du Pasquier-Fediaevsky L, Polak M, Kakou B, Leridon L, et al. Short needles $(8 \mathrm{~mm})$ reduce the risk of intramuscular injections in children with type 1 diabetes. Diabetes Care. 1999; 22(10): 1621-5.

26. Frid A, Hirsch L, Gaspar R, Hicks D, Kreugel G, Liersch $\mathrm{J}$, et al. New injection recommendations for patients with diabetes. Diabetes Metab. 2010; 36 Suppl 2:S3-18. 